ISSN 2519-2523 (print)

Chornomors'ka mynuvshyna. - 2020. - No.15

DOI: $10.18524 / 2519-2523.2020 .15 .218680$

УДК: 94:314.743(477)"1945/1980"

\title{
VOLODYMYR MOSHYNSKY IN THE UKRAINIAN COSSACK MOVEMENT OF THE XX CENTURY
}

\author{
Olexsandr Muzychko \\ ORCID: https://orcid.org/0000-0002-8019-2254 \\ DSc (History), Associate Professor \\ Odessa I. I. Mechnikov National University \\ 2, Dvoryanska Str., Odessa, 65082, Ukraine \\ sandro06@ukr.net
}

The purpose of this article is to study the participation of Volodymyr Moshynsky (1895-1988) in the Ukrainian Cossack movement, who for some time was a representative of the Odessa center of the Ukrainian revolution of 1917-1921, but the main stage of his life took place in North America in the second half of the twentieth century. The article is based on the use of a wide source base of published narrative sources, the most important of which are the memoirs and works of $V$. Moshinsky. Biographical, prosopographic, historical-genetic methods, as well as a number of generally accepted scientific methods were used to implement the tasks. The historiographical work on the figure of $V$. Moshinsky is narrow and clearly inadequate to the scale of his activity. It is mentioned in a limited number of publications and sometimes in a false context. V. Moshynsky's articles show that he was fully aware of his Cossack ancestral roots and was proud of them. There was a harmonious connection between the facts of his biography and his interests, as he had to work in the interwar period in the area where his wife's ancestors came from the Danube Cossacks. In October 1917, during a confrontation with the Bolsheviks in Moscow, V. Moshinsky became friends with the Amur Cossacks, who almost persuaded him to go with them to the Far East. $V$. Moshinsky received scientific information about the history of the Ukrainian Cossacks at lectures of the leading Odessa Cossack scholar M. Slabchenko. The Cossack trace in V. Moshinsky's biography was most clearly reflected in his activity in the Cossack Ukrainian movement in the USA. In the 1970s, he was one of the leaders, clerk, tent of the Ukrainian Free Cossacks in Denver named after the commander, the first knight of the Iron Cross, Colonel-General Mikhail Omelyanovich-Pavlenko. V. Moshynsky received the rank of Cossack lieutenant colonel and later colonel. The main body of the free Cossack movement in the United States was the magazine "Ukrainian Cossacks", published from the late 1960s to the 1980s. V. Moshinsky was mentioned in the pages of this magazine as a donor to its publication, was the author of a number of articles. The magazine covered the artistic activity of $V$. Moshynsky and his children, with the inclusion of this activity in the Cossack context. In 1974, the magazine published an important and so far unique evidence that the Cossack theme was present in the artist's work - a reproduction of his painting in the mid-1950s "Hetman Mazepa before the Battle of Poltava", kept in Montreal, donated to the Women's Society "Daughters of Ukraine". Thus, in the figure of V. Moshinsky we have one of the most original popularizers of the history of the Ukrainian Cossacks, a Cossackpractitioner and a Cossack-artist, a Cossack-memoirist, whose rich life experience united Ukraine and the diaspora with invisible ties, contributed to the preservation of historical memory not the most popular pages of Cossack history. But these pages are the most important for the modern Odessa region, where the problem of saturation of Bessarabia (as well as Odessa and Odessa region in general) with the Ukrainian worldview and culture is acutely relevant. The author considered the Cossacks within the framework of the national tradition, which combined the 
features of populist and state historiography, which was a typical feature of the North American Ukrainian historiographical tradition.

Key words: Southern Ukraine, Odessa, military, Danube Cossacks, Cossacks study.

Олександр Музичко

ORCID: https://orcid.org/0000-0002-8019-2254

Доктор історичних наук, доцент

Одеський національний університет імені I. I. Мечникова

Вул. Дворянська, 2, Одеса, 65082, Україна

sandro06@ukr.net

\section{ВОЛОДИМИР МОШИНСЬКИЙ В УКРАЇНСЬКОМУ КОЗАЦЬКОМУ РУСІ ХХ СТОЛІтТЯ}

Метою иієї статті є дослідження участі в українському козаџькому русі Володимира Мошинського (1895 - 1988), деякий час представника одеського плацдарму Украӥнської револючії 1917 - 1921 років, але основний етап життя якого відбувся вже у Північній Америчі у другій половині XX cm. У постаті В. Мошинського маємо одного з найбільш своєрідних популяризаторів історії украӥнського козачтва, козака-практика та козакамития, козака-мемуариста, багатий життєвий досвід якого єднав незримими узами Украӥну та діаспору, сприяв збереженню історичної пам'яті про не найпомітніші та не найпопулярніші сторінки козачької історії.

Ключові слова: Південна Украӥна, Одеса, військові, Дунайське козачтво, козакознавство.

У сучасній історіографії можна зустріти непоодинокі тези про, мовляв, «застарілість» фактологічної історії та необхідність до зосередження виключно на широких теоретичних, історіософсько-соціологічних узагальненнях. Таким чином, в українські реалії, на жаль, як і багато в іншому, не виважено вкидаються справді слушні для США тенденції тамтешньої історіографії. Для України ж, яка тривалий час фактично була позбавлена власної історіографії і на сьогодні актуальними $\epsilon$ дослідження, що реконструюють на конкретній документальній базі (не боїмося це пов'язати 3 традиціями доброго, старого, позитівізму) частинки колись штучно розбитої мозаїки української історії, при чому найбільш важливими є ті ії аспекти, що відображають історію боротьби за національне «Я», державність, національні світоглядні цінності. Значною мірою ці риси були втілені у новокозацькому, вільнокозацькому русі спочатку на території України, а потім української еміграції/діаспори XX ст. Цей рух тісно переплітався з загальним мілітарним рухом українців, діями українських військових частин УНР та ЗУНР в роки Української революції 1917 - 1921 рр. Персональний вимір історії мілітарного українського руху, зокрема, вільнокозацького, й його еміграційно-діаспорні аспекти, ретельно вивчаються в Україні в останні десятиліття. Варто наголосити, що тривалий час, в умовах російсько-комуністичної окупації України у другій половині ХХ ст., саме еміграція/діаспора були ареалом збереження історичної пам'яті українців, збирання відомостей, публікації документів, аналітики, що було започатковано у міжвоєнній Галичині та Волині.

Метою цієї статті є дослідження участі в українському козацькому русі Володимира Мошинського (1895 - 1988), деякий час представника одеського плацдарму Української революції 1917 - 1921 рр., але основний етап життя якого відбувся вже у 
Північній Америці у другій половині XX ст. Тривале та насичене життя цього непересічного діяча варте комплексного дослідження, чим ми i займаємося i реалізуємо свій доробок у серії подальших статей, але у цій статті зосередимося на козакознавчому аспекті.

Стаття грунтується на використанні широкої джерельної бази опублікованих наративних джерел, найважливішими з яких є мемуари та праці В. Мошинського. Для реалізації завдань використано біографічний, просопографічний, історико-генетичний методи, а також низку загальноприйнятих наукових методів.

Історіографічний доробок щодо постаті В. Мошинського $\epsilon$ вузький i явно неадекватний масштабам його діяльності. Широка громадськість не дізнається про нього ані з діаспорної «Енциклопедії українознавства», ані з новітньої «Енциклопедії історії України». Єдиним поширеним джерелом інформації, де $\epsilon$ стаття про В. Мошинського, є «Енциклопедія сучасної України», де надано основні віхи його біографії. У низці публікацій у діаспорі та в Україні про В. Мошинського згадано передусім як про митця [9, с. 66-67; 26, с. 166; 28]. Основи вивчення В. Мошинського як військового діяча заклав Я. Тинченко, хоча йдеться тільки про згадку дуже поодиноких фактів [27, с. 330, 337].

Не обійшлося, як це часто буває щодо маловідомих постатей, і без трагікомічних парадоксів. Маємо на увазі велику статтю львівського філолога Миколи Крупача, в якій він розгорнув складні реконструкції, в результаті яких «переписав» статті В. Мошинського у варшавській українській газеті «Син України» (до того ж прямо підписані саме «В. Мошинський»!) на авторство Є. Маланюка, який, мовляв, використав прізвище В. Мошинський в якості одного зі своїх псевдонімів [10, с. 3637]. Таким чином, факти біографії В. Мошинського М. Крупач на підставі своїх хибних висновків відніс до біографії Є. Маланюка. Причина цього прикрого випадку банальна, про що повідомив сам автор - він просто не знав про існування постаті В. Мошинського (як тут не згадати і про те, що все ж таки філологам не слід обходитися без істориків у своїй пошуковій діяльності, бо без істориків неможливо наблизитись до адекватного пізнання історії). При тому нам не вдалося виявити в історіографії згадок про козакознавчі аспекти у житті В. Мошинського, що $\epsilon$ предметом розгляду цієї статті.

Козакознавчий аспект тісно вплетений у загальне мереживо життєвого шляху В. Мошинського. Тому намітимо основні контури його ще фактично ненаписаної біографії.

В нас є мінімум даних про перший етап життя В. Мошинського. Народився він 18 червня 1895 р. в селі Турбові на Поділлі (сучасна Вінницька область) у родині Миколи Мошинського та Марії Мефодіївни з роду Богуславських [4]. I батько, і мати походили з родин священиків. Мав брата Миколу, який воював на фронтах Першої світової війни та помер у 1918 р., та трьох сестер, що згодом мешкали в Одесі. Одна 3 них, Лідія, брала участь в українському національному русі, була директоркою першої української школи імені Івана Франка. В. Мошинський закінчив Московську гімназію та Олексіївську військову школу.

Перший, i, слід думати, найнасиченіший, період його життя припав на добу Першої світової війни, Російської та Української революцій. Він служив у 95-му Красноярському полку на Волині. Від весни 1917 р. служив у званні старшини. Був нагороджений солдатським хрестом Св. Георгія [17]. У жовтні-листопаді 1917 р. він був активним учасником боротьби проти більшовиків у Москві на боці Тимчасового 
уряду проти більшовиків. Отже, в Одесі В. Мошинський був прикладом вояка, що мав досвід антибільшовицької боротьби у самому «лігві».

Наприкінці 1917 р. В. Мошинський демобілізувався та приїхав до міста Сквира. У червні 1918 р. - квітні 1920 р. тривав одеський період діяльності В. Мошинського. Мешкав він на Канатній вулиці на розі Пантелеймонівській (дім Віта). Брав участь у теософському гуртку. Працював чорноробом в Одеському залізничному депо з метою поширення української пропаганди до вересня 1918 року. Потім вступив у лави 14-ї стрілецького полку четвертої Залізної бригади, в сотню сотника Вишневського. Охороняв склади. Паралельно навчався у Театральній українській студії, брав участь в організації українських театральних вистав [21]. В. Мошинський був одним 3 активних учасників Української революції в Одесі, помічником адмірала М. Остроградського, організатором та членом української військової організації Одеси. На початку грудня він увійшов до 14-ої бригади Української Галицької армії, що розташовувалась в касарнях на Грецькій вулиці.

У 1920 р. В. Мошинському вдалося вибратися з окупованої комуністами Одеси, переїхати до польського Тарнува та зустрітися з С. Петлюрою. У 1921 - 1922 рр. В. Мошинський діяв у складі надзвичайної дипломатичної місії УНР у Румунії у званні молодшого старшини для зв'язку відділу повстанських організацій генерального штабу. Судячи з його листа до шефа військової секції місії генерала С. Дельвіга, сотник В. Мошинський мав з території Молдови потрапити до Одеси в якості розвідника, але на заваді став корупційний скандал у середовищі причетних до цієї справи румунських та українських уповноважених [3, с. 146-147].

Однак на території тогочасної Румунської держави, в Ізмаїлі, він залишився надовго, аж до 1944 р., живучи за нансенівським паспортом. Він розмальовував бессарабські та румунські церкви, меморіали. Наприкінці життя він тепло згадував про ці роки: «Південь Бессарабії - милий моєму серцеві край! Це край, у якому я зазнав щастя любові, де одружився 3 коханою дівчиною, прожив 24 роки молодого життя й де з дружиною виростили на користь Україні своїх трьох дітей. Не дивлячись на утиски румунської влади... той край залишається в моїх споминах найкращий. Тут, у США, з прекрасної далечини, згадуються мені моменти моєї тодішньої творчості 3 якоюсь душевною радістю, а моменти невигод i неприємностей, якось затушовуються, зникають в темряві років» [16, с. 9].

У післявоєнний період мешкав в Австрії. У 1950 р. В. Мошинський переїхав до Монреалю. Тут він був активним учасником «Союзу бувших українських вояків у Канаді», був нагороджений Хрестом Симона Петлюри за участь у збройній боротьбі за державність та Воєнним хрестом [27, с. 330, 337].

«Тут, у США, я зміг ширше розправити свої крила і свої думки - мрії мистця багато легше мені перетворити в дійсність, в образи!», - згадував він [16, с. 9].

Він розмалював 7 церков. Головним чином у штаті Мен. Виконав понад сотню портретів (югославського короля Александра, американця Ловелла Томаса на замовлення Денверського університету). Створений ним портрет митрополита А. Шептицького був придбаний для австрійського замку. В. Мошинський був іконописцем у рідкісній техніці малювання ікон на золотому чеканному тлі. Його пензлю належать такі картини як «Св. Володимир», «Свята Родина», «Архангел Михаїл», «Хрещення України», краєвиди [1][12]. У 1986 р. отримав приз «Тһе American by Choise Award». Цю нагороду надавали щороку двом найбільш значимим мешканцям штату Колорадо з числа натуралізованих громадян в день громадянства 17 вересня за їхній внесок у культурний та суспільний розвиток штату. 
В. Мошинський був першим митцем, хто отримав цю нагороду в іiї історії вручень, бо до нього її отримували лише громадські та суспільні діячі [13].

Передусім був оцінений внесок митця у популяризацію історії штату Колорадо. У день 88-річчя В. Мошинський отримав привітання від президента США Р. Рейгана та його дружини Ненсі [24]. В ювілейній статті до 70-річчя митця сучасник зазначив, що у свої 70 років він «виглядає як справжній козарлюга, молодий духом і тілом» [11, с. 28]. Козацький слід виразно відбився не тільки у поставі митця, але й загалом в його життєвому шляху.

Вже на схилі років, у 1974 р., В. Мошинський в окремій статті висвітлив свій козацький родовід [20]. I хоча не навів точних даних, показовий вже сам факт цієї саморефлексії митця. Він згадував, що на запитання про родовід, його батько розповідав йому, що, згідно з родинними переказами, Мошинські ведуть свій родовід від козака Мошни $з$ містечка Мошна, хоча сам батько народився вже у родині священика на Київщині. Намагаючись поглибити козацький аспект своєї біографії, В. Мошинський згадав про відповідні коріння своєї дружини - ізмаїльчанки Лариси Захарівни Чайківської. ІІЇ батько, священик Захарій, розповідав про те, що колись на Дунайську Січ прийшло три брати, один з яких був дідом Захарія, а його батько теж певний час був січовиком-задунайцем, а потім - Буджацького (Дунайського) козацького війська, що проіснувало до 1868 р.

Ці тези В. Мошинського підтверджуються нотатками його сина Юрія про зустріч у Франції з братом його матері Іваном. Юрій зауважив, що незважаючи на довгі роки еміграції, «Все таки старокозацька кров у ньому не застигла, і він часто згадує свого діда та прадіда, що були одними з ранніх емігрантів з України на Задунайську Січ» $[23$, c. 148,176$]$.

У жовтні 1917 р. у Москві під час протистояння з більшовиками В. Мошинський приятелював 3 приамурськими козаками, які ледве не умовили його поїхати з ними на Далекий Схід. У 1918 р. В. Мошинський отримав наукову інформацію про історію українського козацтва на лекціях провідного одеського козакознавця Михайла Слабченка, свого професора у театральній студії імені Марка Кропивницького в Одесі [21, с. 1255].Найвиразніше козацький слід у біографії В. Мошинського відбився в його діяльності у козацькому українському русі у США. У 1970-х роках він був одним із провідників, писарем, куреня українського вільного козацтва в Денвері імені командарма, першого лицаря залізного хреста, генерал-полковника Михайла Омеляновича-Павленка. В. Мошинський отримав звання козацького підполковника та згодом полковника. У звіті про діяльність осередку колишній сотник армії УНР висловив думку, що українське вільне козацтво є станова, парамілітарна, не політична і не партійна організація, що має єднатися навколо боротьби за реалізації величної ідеї Української Самостійної Соборної Держави. «Мусимо працювати для цієї ідеї, підтримувати дух цієї ідеї, за яку боролися ми в Визвольних змаганнях, за яку проливали кров наші брати і сестри, за яку борються і тепер одчайдухи на наших рідних землях... Слава високим ідеям Козацтва! Слава Українському Вільному козацтву!», - наголошував він [19, с. 67].

Основним органом вільнокозачого руху у США був часопис «Українське козацтво», що видавався 3 кінця 1960-х - у 1980-х роках [2]. В. Мошинський вказувався на сторінках цього часопису як жертводавець на його видання. У 1979 р. у листі до редакції він писав: «журнал, Вами створений, займає почесне місце в цілій українській періодиці, це вже відмічено і це не є комплімент, а правда...» [18, с. 40]. 
У часописі висвітлювалась мистецька діяльність В. Мошинського та його дітей, 3 внесенням цієї діяльності у козацький контекст [8].

У 1974 р. часопис опублікував важливе і поки що унікальне свідчення про те, що козацька тематика була присутня у творчості митця - репродукцію його картини середини 1950-х років «Гетьман Мазепа перед Полтавським боєм», що зберігалася у Монреалі, подарована свого часу Жіночому товариству «Доньки України» [5].Окрім двох вже згаданих статей (про козацький родовід родини та звіт про діяльність куреня українського вільного козацтва) у часописі було оприлюднено ще дві статті В. Мошинського. У 1982 р. В. Мошинський надрукував фрагмент своїх спогадів про один 3 найяскравіших епізодів в його житті - участь у засіданнях першого українського військового з’їзду 1917 р. [17]. Проте, козацької тематики у цій статі не було.

Тому значно важливішою є його попередня велика публікація, 1973 р., про задунайських козаків, Задунайську Січ [15]. Відкривав працю промовистий епіграфпосвята священику Захарію Чайківському, його дітям Миколі та Івану та своїй дружині Ларисі - нащадкам дунайських козаків. Автор грунтовно підійшов до висвітлення питання, навівши багато фактів, чим сприяв популяризації не типової для діаспорної історіографії тематики.

Але цінність статті полягала не у наведенні загальновідомих і на той час і тим більше нині даних, або новій методології чи історіософії (автор, звичайно, розглядав козаків в рамках націєтворчої традиції, що поєднувала риси народницької та державницької історіографії, що було типовою рисою північноамериканської української історіографічної традиції), а у фіксації автобіографічної інформації, передусім у жанрі усної історії, що є свідченням про циркулювання історичної пам'яті про козацтво у цьому регіоні. В. Мошинський згадав про своє перебування у цій місцевості на зламі 1930-х - 1940-х років, докладно описав свої бесіди зі старожилами, дунайцями, нащадками козаків, тим самим продовживши традицію усної історії щодо цього питання, яку започаткували, зокрема, одеські історики кінця XIX - початку XX ст. [6; 7; 25]. Завершив свою статтю В. Мошинський промовистим пасажем, що може бути використаний i зараз у відповідних наративах: «Так, починаючи 3 кінця 16-го і майже до кінця 19-го століття українське козацтво густо поливало своєю кров'ю землі навколо гирла Дунаю, що ніс лицарську козачу кров у наше Сорне море... Три століття боротьби, звитяжства і слави!» [15, с. 16]У тому ж 1973 р. в одному 3 провідних часописів української діаспори ця стаття В. Мошинського, хоч і під такою самою назвою, була видана у значно більш доповненому вигляді [14]. Зокрема, автор більше уваги приділив участі козаків у штурмі Ізмаїлу 1790 р. Також автор мав можливість розширити мемуарну частину і саме про своє перебування в Ізмаїлі та Кілії у міжвоєнний період. У 1943 р. В. Мошинський виконав доручення намалювати чотири ікони у каплиці на цвинтарі невідомим воякам Першої світової війни в Ізмаїлі.

Показовим є в контексті нашої теми спогад В. Мошинського про мотивацію своєї праці: «я відчував велику приємність, що мені доручено розмалювати каплицюпам'ятник, бо цей пам'ятник був не тільки пам'ятником воякам, що загинули у першу світову війну, а й символічним пам'ятником «крови», яку колись пролляли на валах $\mathrm{i}$ мурах Ізмаїльської фортеці також запорожці; тут була й українська кров, хоч i проллята за чужу справу» [14, с. 1330]. Ілюструючи цю тезу, митець згадав про дії козаків у цій місцевості у часи Наливайка. Більш докладно були висвітлені обставини виникнення Задунайської Січі та побуту задунайців. Деякі автобіографічні 
зауваження пересипані художньою уявою митця. Так, описуючи своє плавання по зимовому Дунаю поблизу Ізмаїла, В. Мошинський згадував, що йому тоді спали на думку історичні події 1790 р.: «Тоді запорозькі козаки з флотилії де Рібаса нишком пливли по Дунаю уночі, робили розвідку, іноді натрапляючи на сильні стежі турків на каюках, зчиняли з ними бій. Це було давно, а здавалося, начебто вчора! Може і тоді йшла крига, може й тоді запорожці чули той шерех криг...» [14, с. 1342]. Втім, якщо стаття в «Українському козацтві» мала оптимістичне закінчення, то у цій статті останнє речення В. Мошинського виглядало значно більш песимістично-критично: «Але, на жаль, всі ті звитяги, всі ті жертви були, переважно, на користь не Україні, а їі ворогам - москалям або туркам!».

У переробленому вигляді стаття В. Мошинського про дунайське козацтво була надрукована у 1980 р. в іншому американському українському часописі. Щоправда, найцінніші фрагменти своєї публікації він саме звів до мінімуму [16].

В обох статтях В. Мошинський згадував про липован та їх взаємини 3 дунайськими козаками. В окремій публікації він справедливо виправив помилкове твердження про те, що липовани, це, мовляв, є різновид українців [22]. Ця стаття, як $\mathrm{i}$ стаття 1973 р. у часописі «Українське козацтво», насичена цінними для історика липован та Українського Придунав'я автобіографічними деталями, що ілюстрували думку автора про абсолютну нетотожність і навіть часто-густо ворожість один до одного липован та українців, зокрема, козаків.

Отже, у постаті В. Мошинського маємо одного 3 найбільш своєрідних популяризаторів історії українського козацтва, козака-практика та козака-митця, козакамемуариста, багатий життєвий досвід якого єднав незримими узами Україну та діаспору, сприяв збереженню історичної пам'яті про не найпомітніші та не найпопулярніші сторінки козацької історії. Але саме ці сторінки є найважливішими для сучасної Одещини, де гостро актуальною є проблема насичення Бессарабії (як, втім, й Одеси та Одещини загалом) українським світоглядом, культурою. Життєвий досвід та тексти маестро-Мошинського, як називали його сучасники, є чудовим євшан-зіллям.

\section{Джерела та література:}

1. Биковський Л. Десять років науково-організаційної праці на Заході США (Денверська група УВАН) / Л. Биковський // Визвольний шлях. - 1966. - № 7-8. - С. 957-966.

2. Богуславський О. В. Журнал «Українське Козацтво» як речник військової думки повоєнної української еміграції / О. В. Богуславський // Поліграфія і видавнича справа : наук.-техн. зб.- 2002. - № 39. - С. 82-86.

3. Власенко В. М. Документи і матеріали надзвичайної дипломатичної місії УНР у Румунії (1919-1923 рр.) / В. М. Власенко // Пам’ятки: археографічний щорічник. - К., 2008. - Т. 8. С. 129-160.

4. Жила В. Справжнє мистецьке зусилля не пропадає (До 92-річчя 3 дня народження митця В. Мошинського) / В. Жила // Свобода. - 1987. - 13 лютого.

5. 3 багатого дорібку підполк. УК В. Мошинського // Українське козацтво. - 1974. - Ч. 1. - С. 17.

6. Иванов П. Иванов П.А. А. К истории Запорожских казаков после уничтожения Сечи / П. А. Иванов // Записки Одесского общества истории и древностей (ЗООИД). - 1904. - Т. 25. (Протоколы). - С. 20-40

7. Иванов П. А. Черноморские казаки в Слободзее / П. А. Иванов // ЗООИД.- 1902. T. XXIV. - C. 81-91.

8. Іващук В. Мистецькі осяги козацької родини Мошинських / В. Іващук // Українське козацтво. - 1971. - Ч. 4. - С. 40-41.

9. Кейван І. Українські мистці поза Батьківщиною / І. Кейван. - Едмонтон, 1996. - 227 с. 
10. Крупач М. Пошуки дотаборових публікацій Євгена Маланюка (1916-1917 та 1920 років) / М. Крупач // Українське літературознавство. - 2013. - Вип. 77. - С. 3-44.

11. Крупський К. Родина мистців / К. Крупський // Овид. - 1965. - № 4. - С. 25-28.

12. Л. Б. Денверська група УВАН / Л. Б.// Українські вісті. - 1969. - 13-20 квітня. - С. 3.

13. Михайленко О. Українець одержав нагороду «Американець за вибором»/ О. Михайленко // Свобода. - 1987. - 28 січня.

14. Мошинський В. Дунайське козацтво / В. Мошинський // Визвольний шлях. - 1973. - Кн. 11/12. - С. 1324-1346.

15. Мошинський В. Дунайське козацтво / В. Мошинський // Українське козацтво. - 1973. Ч. 3. - С. 9-16.

16. Мошинський В. Дунайське козацтво / В. Мошинський // Нові дні. - 1980. - Квітень. C. 9-12.

17. Мошинський В. 3 далекого минулого (Спогад) / В. Мошинський // Українське козацтво. - 1982. - Ч. 1. - С. 50-57.

18. Мошинський В. Лист до редакції / В. Мошинський // Українське козацтво. - 1979. - Ч. 5. - C. 40 .

19. Мошинський В. 3 діяльності куреня УВК Ч. 16 ім. командарма, першого лицаря залізного хреста, генерал-полковника Михайла Омеляновича-Павленка, в Денвері / В. Мошинський // 1980. - № 1-3. - С. 66-69.

20. Мошинський В. Родинні зв'язки Мошинських і Чайківських 3 козацтвом / В. Мошинський // Українське козацтво. - 1974. - Ч. 2. - С. 16-17.

21. Мошинський В. Український державний театр ім. Т. Шевченка в Одесі й театральна студія ім. М. Кропивницького: (зі споминів про Одесу) / В. Мошинський // Визвольний шлях. - 1966. - Кн. 11. - С.1247-1262.

22. Мошинський В. Чи липовани - це українці? (до історії поселення Південної Бесарабії). / В. Мошинський. - Нью-Йорк, 1955. - 8 с.

23. Мошинський Ю. У світі мистецьких чарів. Враження з подорожі. / Ю. Мошинський. Чикаго, 1963. - $326 \mathrm{c.}$

24. Олінкевич-Колодій А. Вісті з Денверу / А. Олінкевич-Колодій // Свобода. - 1983. 21 липня.

25. Петлюра С. В. Рец. на: Иванов П.А. К истории Запорожских казаков после уничтожения Сечи / С. В. Петлюра // Записки наукового товариства ім. Т. Шевченка. - 1905. - Т. 63 Бібліографія. - С. 22-23.

26. Тимків Б. М. Мистецтво України та діаспори: дереворізьба сакральна й ужиткова / Б. М. Тимків. - Івано-Франківськ: Нова Зоря, 2009. - 206 с.

27. Тинченко Я. Офіцерський корпус Армії Української Народної Республіки (1917-1921) / Я. Тинченко. - Київ : Темпора, 2011. - Кн. 2. -422 с.

28. Трембіцький А. М. Часопис «Нотатки 3 мистецтва» (Філадельфія) об'єднання мистців українців в Америці про життєві шляхи і творчу діяльність мистців-подолян / А. М. Трембіцький // Освіта, наука і культура на Поділлі. - 2014. - Т. 21. - С. 234-256.

\section{References:}

1. Bykovs'kyy, L., 1966. Desyat' rokiv naukovo-orhanizatsiynoyi pratsi na Zakhodi SShA (Denvers'ka hrupa UVAN). Vyzvol'nyy shlyakh, 7-8, pp. 957 - 966.

2. Bohuslavs'kyy, O. V., 2002. Zhurnal «Ukrayins'ke Kozatstvo» yak rechnyk viys'kovoyi dumky povoyennoyi ukrayins'koyi emihratsiyi. Polihrafiya $i$ vydavnycha sprava : nauk.-tekhn. zb., 39, pp. 82-86.

3. Vlasenko, V. M., 2008. Dokumenty i materialy nadzvychaynoyi dyplomatychnoyi misiyi UNR u Rumuniyi (1919-1923 rr.). Pam"yatky: arkheohrafichnyy shchorichnyk, 8., pp. 129-160.

4. Zhyla, V., 1987. Spravzhnye mystets'ke zusyllya ne propadaye (Do 92-richchya z dnya narodzhennya myttsya V. Moshyns'koho). Svoboda, 13 lyutoho.

5. Z bahatoho doribku pidpolk. UK V. Moshyns'koho, 1974. Ukrayins'ke kozatstvo, 1, p. 17. 
6. Yvanov, P. A., 1902. Chernomorskye kazaky v Slobodzee. Zapysky Odesskoho obshchestva ystoryy y drevnostey, XXIV, pp. 81-91.

7. Yvanov, P. A., 1904. K ystoryy Zaporozhskykh kazakov posle unychtozhenyya Sechy. Zapysky Odesskoho obshchestva ystoryy y drevnostey, XXV (Protokoly), pp. 20-40.

8. Ivashchuk, V., 1971. Mystets'ki osyahy kozats'koyi rodyny Moshyns'kykh. Ukrayins'ke kozatstvo, 4, pp. 40-41.

9. Keyvan, I., 1996. Ukrayins'ki mysttsi poza Bat'kivshchynoyu. Edmonton.

10. Krupach, M., 2013. Poshuky dotaborovykh publikatsiy Yevhena Malanyuka (1916-1917 ta 1920 rokiv). Ukrayins'ke literaturoznavstvo, 77, pp. 3-44.

11. Krups'kyy, K., 1965. Rodyna mysttsiv. Ovyd, 4, pp. 25-28.

12. L.B., 1969. Denvers'ka hrupa UVAN. Ukrayins'ki visti, 13-20 kvitnya, p. 3.

13. Mykhaylenko, O., 1987. Ukrayinets' oderzhav nahorodu «Amerykanets' za vyborom». Svoboda, 28 sichnya.

14. Moshyns'kyy, V., 1973. Dunays'ke kozatstvo. Vyzvol'nyy shlyakh, 11/12, pp. 1324-1346.

15. Moshyns'kyy, V., 1973. Dunays'ke kozatstvo. Ukrayins'ke kozatstvo, 3, pp. 9-16.

16. Moshyns'kyy, V., 1980. Dunays'ke kozatstvo. Novi dni, kviten', pp. 9 - 12.

17.Moshyns'kyy, V., 1982. Z dalekoho mynuloho (Spohad). Ukrayins'ke kozatstvo, 1, pp. 50-57.

18. Moshyns'kyy, V., 1979. Lyst do redaktsiyi. Ukrayins'ke kozatstvo, 5, p. 40.

19. Moshyns'kyy, V., 1980. Z diyal'nosti kurenya UVK Ch. 16 im. Komandarma, pershoho lytsarya zaliznoho khresta, heneral-polkovnyka Mykhayla Omelyanovycha-Pavlenka, v Denveri. Ukrayins'ke kozatstvo, 1-3, pp. 66-69.

20. Moshyns'kyy, V., 1974. Rodynni zv"yazky Moshyns'kykh i Chaykivs'kykh z kozatstvom. Ukrayins'ke kozatstvo, 2, pp. 16-17.

21. Moshyns'kyy, V., 1966. Ukrayins'kyy derzhavnyy teatr im. T. Shevchenka v Odesi y teatral'na studiya im. M. Kropyvnyts'koho: (Zi spomyniv pro Odesu). Vyzvol'nyy shlyakh, 11, pp.1247-1262.

22. Moshyns'kyy, V., 1955. Chy lypovany - tse ukrayintsi? (do istoriyi poselennya Pivdennoyi Besarabiyi). N'yu-York.

23. Moshyns'kyy, Yu., 1963. U sviti mystets'kykh chariv. Vrazhennya z podorozhi. Chykaho.

24. Olinkevych-Kolodiy, A., 1983. Visti z Denveru. Svoboda, 21 lypnya.

25. Petlyura, S. V., 1905. Rets. na: Yvanov P.A. K ystoryy Zaporozhskykh kazakov posle unychtozhenyya Sechy. Zapysky naukovoho tovarystva im. T. Shevchenka, 63 (Bibliohrafiya), pp. $22-23$.

26. Tymkiv, B. M., 2009. Mystetstvo Ukrayiny ta diaspory: derevoriz'ba sakral'na y uzhytkova. Ivano-Frankivs'k: Nova Zorya, $206 \mathrm{p}$.

27. Tynchenko, Ya., 2011. Ofitsers'kyy korpus Armiyi Ukrayins'koyi Narodnoyi Respubliky (1917-1921), Vol. 2. Kyiv: Tempora.

28. Trembits'kyy, A. M., 2014. Chasopys «Notatky z mystetstva» (Filadel'fiya) ob"yednannya mysttsiv ukrayintsiv v Amerytsi pro zhyttyevi shlyakhy i tvorchu diyal'nist' mysttsiv-podolyan. Osvita, nauka i kul'tura na Podilli, 21, pp. 234-256.

Отримано: 24.11.2020 p. 